\title{
Nominal Wage Flexibility and Monetary Union
}

\author{
Jules Leichter \\ U.S. Department of the Treasury
}

\begin{abstract}
The impact of the creation of a monetary union on structural convergence among member countries remains an open question. A model of monetary union is presented in which national nominal wage flexibility is endogenous and may vary across countries. We use wage indexation as a proxy for nominal wage flexibility and show how the strategic interaction between the monetary union central bank and wage bargainers results in "outlier" countries choosing an optimal wage contract which creates a more flexible nominal wage. The model predicts that if national business cycles are not perfectly synchronized, the optimal response of labor market participants to the creation of a single currency may promote structural divergence among member countries.
\end{abstract}

- JEL Classifications: E50, F33, J50

- Key words: Monetary union, Wage flexibility, Structural convergence

\section{Introduction}

Structural differences among monetary union (MU) members play an important role in the study of the optimal common monetary policy. Benigno (2001) finds that the aggregate inflation target for a MU central bank should put a larger weight on the inflation rate of countries with a higher degree of nominal rigidity. The existing literature on the European single currency has documented existing differences in national monetary transmission mechanisms but has not addressed

\footnotetext{
*Corresponding address: Doctor Jules Leichter, U.S. Department of the Treasury, 1500 Pennsylvania Avenue NW, Washington DC 20220, USA. Tel: +1-202-622-0184, Fax: +1-202-622-0037, E-mail: jules.leichter@do.treas.gov

(O2004-Center for International Economics, Sejong Institution, All Rights Reserved.
} 
the impact of the creation of the single currency on the degree of nominal wage flexibility in member countries. ${ }^{1}$ This paper presents a model of a MU in which the degree of nominal wage flexibility is endogenous and is altered by the creation of a single currency. ${ }^{2}$ In particular, it is found that labor market participants in countries whose real shocks have a low correlation with aggregate MU shocks (henceforth referred to as "outlier" countries) endogenously adjust to a MU by creating a more flexible nominal wage relative to their counterparts in "core" countries. Intuitively, a common monetary policy geared towards stabilizing aggregate MU economic fluctuations results in undesired nominal shocks in outlier countries. Therefore, labor market participants in these countries find it optimal to choose a flexible nominal wage contract which partially insulates them from these undesired monetary policy interventions.

The literature on structural convergence in a MU has generally treated structural reform as a government choice variable but has not modeled explicitly how markets would react to this new monetary regime. ${ }^{3}$ This endogenous reaction by labor market participants has been noted by European policy makers. In a report to the EU, Emerson et al (1990) concludes:

the effects of EMU on wage flexibility are largely dependent, either directly or indirectly, on economic agents determining and influencing wage behavior. For governments this concerns the reaction to temporary shocks, whereas the participants in the wage bargaining process would have to take account of the implications of EMU in the field of inflation expectations and its effect on real exchange rates.

The creation of a fixed exchange rate regime or a MU has important effects on the strategic interaction between the monetary authority and labor market participants. Consider the following two possible changes to the central bank objective function:

\footnotetext{
${ }^{1}$ For an empirical comparison of the monetary transmission mechanisms across European countries see Gerlach and Smets (1995), Dornbusch, Favero and Giavazzi (1999), Ramaswamy and Slok (1998), Sala (2000), Leichter and Walsh (2000), among others.

${ }^{2}$ Calmfors and Johansson (2002) study a similar question in an open economy model.

${ }^{3}$ See Calmfors (2001), Sibert (1999) and Beetsma and Jensen (1998) for models of structural convergence in a MU. Cukierman and Lippi (1999) study how the creation of a MU affects the strategic interaction between labor unions and the central, bank but do not model explicitly the impact on wage indexation or contract length.
} 
- an increase in the degree of conservativeness

- a change in the variables targeted

In the first case, a country in which monetary policy had failed to control inflation would receive a boost in credibility that would reduce incentives for indexing contracts. One can argue, for instance, that Italy enjoyed a gain in monetary policy credibility after joining the Exchange Rate Mechanism (ERM), allowing for the elimination of the national indexation scheme (scala mobile). ${ }^{4}$

Eichengreen (1993) shows that inflation persistence was lower during BrettonWoods than after. He concludes that this was incorporated into wage contracts, resulting in more flexible wages. ${ }^{5}$ In the second case, a MU central bank is concerned with aggregate rather than country-specific output and inflation stabilization. A country with output fluctuations that are poorly correlated with aggregate MU fluctuations would experience a higher variance of nominal shocks caused by undesired monetary policy interventions. In theory, this would increase the incentive for higher wage indexation and would result in a more flexible nominal wage. The impact of a MU on nominal wage flexibility is explored in this paper.

This paper presents a model in which the post-MU strategic interaction between national trade unions and the common monetary policy alters incentives trade unions face when bargaining wage contracts and results in new levels of nominal wage flexibility in member countries. The model uses wage indexation as a proxy for nominal wage flexibility. ${ }^{6}$ Country-specific shocks are added to the Walsh (1995) optimal wage indexation framework to study how the degree of asymmetry between members of a MU affects indexation, and therefore the degree of nominal wage flexibility. It is shown that trade unions in outlier countries demand higher levels of wage indexation, and therefore create a more flexible nominal wage. The result suggests that structural convergence or divergence between MU members will depend on the impact of the new monetary regime on the synchronization of business cycles across countries.

\footnotetext{
${ }^{4}$ See Barrell (1990).

${ }^{5}$ The paper presents the case that the credibility gains from the fixed exchange rate regime made government interventions more effective.

${ }^{6}$ One could also use contract length as a proxy for nominal wage rigidity. See the seminal work by Gray (1978) and more recent work by Danziger (1988) on the relationship between economic uncertainty and contract length.
} 
The paper is organized as follows. Section 2 reviews the optimal wage indexation literature. Section 3 presents an optimal wage indexation model with country-specific shocks. Section 4 discusses the implications of the model for structural convergence in a MU. Section 5 gives some concluding remarks.

\section{Optimal Wage Indexation Literature}

The endogeneity of wage indexation is addressed in Gray (1976) and Fischer (1977). They show that wage indexation provides trade unions with a tool to insulate themselves partially from the effect of nominal shocks during the period of the contract. By choosing full indexation, they create a flexible nominal wage which optimally adjusts to demand shocks. When supply shocks are present, unions prefer a flexible real wage to maintain the employment level desired. When non-trivial real and nominal shocks are present, unions choose partial indexation. ${ }^{7}$ More recent literature on wage indexation has used a Barro-Gordon (1983) game to model the interaction between the central bank and private agents. The level of indexation chosen by economic agents alters the slope of the Phillips curve, thus affecting incentives for the central bank to create surprise inflation. Conversely, the degree of conservativeness of the central bank indicates how much stabilization policy it is willing to undertake, thus affecting the economic agents' incentives to protect themselves against real and nominal shocks. This framework has been used to study the impact of wage indexation decisions on the classic inflationary bias problem. Devereaux (1987) shows that it is possible for increased monetary variability to be welfare increasing if it induces trade unions to increase indexation by reducing the incentive of the central bank to inflate. Waller and VanHoose (1992) show that when wage bargaining is decentralized, indexation is too low from a social perspective because private agents fail to consider how their indexation choices affect aggregate indexation and, therefore, trend inflation.

The model presented below uses the Barro-Gordon framework to study the strategic interaction between the monetary authority and trade unions, but abstracts from the inflationary bias problem by dropping the assumption that there

\footnotetext{
${ }^{7}$ The evidence on the impact of nominal and real uncertainty on wage indexation and contract length is mixed. There is some evidence that increased nominal uncertainty leads to increased indexation and shorter contract length, but there is less evidence supporting the role of the relative nominal to real shock variances in determining indexation. See Holland (1995), Bils (1991), Fethke (1985) Christofides and Stark (1996), Ahmed (1987) and Murphy (2000).
} 
is a wedge between the trade unions' and the central bank's output target. Since the goal is to isolate the effect of idiosyncratic shocks on the strategic interaction between the central bank and country-specific unions, the model presented below assumes that the central bank is allowed to move after the realization of a real shock (henceforth, referred to as stabilization policy) and before the realization of a nominal shock. ${ }^{8}$ This assumption is realistic given that monetary policy makers are allowed to set policy every few weeks, while bargaining over wages occurs far less frequently. The timing of the nominal shock has the standard interpretation as a price level control error. Hutchison and Walsh (1998) use this informational structure to analyze how increasing central bank independence (CBI) alters the output inflation trade-off, but they do not consider a more drastic monetary regime change like the creation of a MU.

\section{The Model}

A model of wage indexation for members of the European single currency requires a game between a single central bank and multiple trade unions. To analyze how the degree of asymmetry between members of the MU affects indexation demands, idiosyncratic shocks are added to the Walsh (1995) framework. Although each country experiences a different real shock, indexing their wages to a European price level is their only source of insulation from real and nominal shocks. ${ }^{9}$ Trade unions choose nominal wages and levels of indexation before the realization of a real and a nominal shock. After the aggregate real shock has been observed, the central bank chooses a "planned" price level (the actual price level is the central bank choice variable plus a random nominal shock). The Nash equilibrium yields the aggregate price level and a set of country-specific levels of wage indexation. The set of countries is indexed on $[0,1]$.

\footnotetext{
${ }^{8}$ When the central bank is allowed to completely offset nominal shocks, the results are drastically different. For example, VanHoose and Waller (1991) show that when the central bank moves after the realization of both types of shocks, unions choose zero indexation. This occurs because the monetary authority completely offsets nominal shocks, so zero indexation allows a flexible real wage to adjust to changes in the marginal productivity of labor. Bar-Ilan and Zanello (1996) have a similar result when the central bank is assumed to adopt a policy rule which completely offsets nominal shocks.
}

${ }^{9}$ See Duca and VanHoose (1991) for a model with sector specific real shocks where contracts can be indexed to both the price level and sector specific profits. Allowing for wage indexation to sector specific profits in a MU model with endogenous monetary policy is an interesting topic for future research. 


\section{A. The Economy}

The economy for Country $i$ is defined by a production function:

$$
y_{i}=\alpha_{1} l_{i}+\theta_{i}
$$

where $y_{i}$ is the log of output, $l_{i}$ is the $\log$ of labor and $\theta_{i}$ is a country-specific iid productivity shock. All time indices have been suppressed. Expectations are taken at time $t-1$ (before the realization of the shocks). Except for the productivity shock variable, production functions are identical across countries. Perfectly competitive firms set the marginal product of labor equal to the real wage to determine labor demand:

$$
l_{i}=\frac{1}{1-a_{1}}\left(w_{i}-p-\theta_{i}-\ln a_{1}\right)
$$

We assume no labor mobility. Each country has a monopoly union which chooses nominal wages $\left(w_{i}{ }^{9}\right)$ and the level of indexation $\left(b_{i}\right)$ to yield the following nominal wage contract:

$$
w_{i}=w_{i}^{0}+b_{i}\left(p-p^{e}\right)
$$

where $p^{e}$ is the expected, aggregate, union-wide price level. Each union minimizes the following loss function:

$$
E\left[l_{i}-l_{i}^{*}\right]^{2}
$$

where $l_{i}{ }^{*}$ is the union's employment target. The aggregate variables are defined by:

$$
\int b_{i} d i \equiv b \int y_{i} d i \equiv y \quad \int l_{i} d i \equiv l
$$

The country-specific real shocks have the following form:

$$
\theta_{i} \equiv e_{i}+\alpha_{i} \theta \text { where } \int e_{i} d i=0
$$


Normalizing the integral of the $\alpha_{i}^{\prime} \mathrm{s}^{10}$ to one:

$$
\int \alpha_{i} d i=1 \text { yields } \int \theta_{i} d i=\int\left(e_{i}+\alpha_{i} \theta\right) d i=\theta
$$

The sum of all the country-specific shocks is denoted $\theta$ and is interpreted as the aggregate "MU shock." The $\alpha_{i}$ represents the covariance between a country's shock and the aggregate shock (normalized by the variance of the aggregate shock), and $e_{i}$ is interpreted as the idiosyncratic component of the country-specific shock. The main objective of this paper is to determine how the union's indexation choice is affected by the magnitude of $\alpha_{i}$ and the MUCB's monetary policy.

\section{B. Central Bank Optimization}

The MUCB's objective function is the classic Barro-Gordon loss function:

$$
E\left\lfloor\left(y-y^{*}\right)^{2}+c\left(p-p^{*}\right)^{2}\right\rfloor
$$

The more conservative the central bank is the larger the weight it places on the inflation term. A surprise jump in the price level will increase output toward $y^{*}$ but will result in costly price level variability. The actual price level is the central bank's choice $\left(p^{p}\right)$ plus a random control error:

$$
p=p^{p}+v
$$

where $v$ is an iid shock. The central bank chooses $p^{p}$ to minimize (8) subject to (9) and:

$$
y=a\left(p-w^{0}-b\left(p-p^{e}\right)+\ln a_{1}\right)+(1+a) \theta
$$

taking the aggregate level of wage indexation $(b)$, the aggregate nominal wage $\left(w^{0}\right)$ and price expectations $\left(p^{e}\right)$ as given and $a \equiv \frac{a_{1}}{\left(1-a_{1}\right)}$. The central bank's optimal choice is given by:

$$
p^{p}=\frac{a(1-b) y^{*}+c p^{*}+a^{2}(1-b)\left(w^{0}-b p^{e}-\ln a_{1}\right)-a(1-b)(1+a) \theta}{c+a^{2}(1-b)^{2}}
$$

\footnotetext{
${ }^{10} \mathrm{I}$ assume $\alpha_{i}^{\prime}$ s are finite and integrable over $[0,1]$.
} 
The expected price level consistent with rational expectations is:

$$
p^{e}=\frac{a(1-b) y^{*}+c p^{*}+a^{2}(1-b)\left(w^{0}-\ln a_{1}\right)}{c+a^{2}(1-b)^{2}+a^{2}(1-b) b}
$$

By combining (9), (11), (12), the price level can be written:

$$
p=p^{e}+d \theta+v
$$

where $d$ is defined by the following expression:

$$
d=-\frac{a(1-b)(1+a)}{c+a^{2}(1-b)^{2}}
$$

Surprise inflation is a function of the central bank reaction to the aggregate real shock and a random control error.

The stabilization parameter described in (14) plays an important role in the analysis below. For $0<b<1$, this parameter has the following properties:

$\bullet d<0$

- for any level of aggregate indexation, an increase in $c$ lowers $|d|$

The first property embodies the countercyclical nature of the central bank reaction to real shocks. ${ }^{11}$ When faced with a negative (positive) real shock, the central bank creates surprise inflation (deflation) to lower (raise) the real wage in order to partially stabilize the economy around its output target. The second property states that an increase in the weight of the inflation portion of the central bank's objective function will affect the magnitude of the stabilization. This is intuitive since the more conservative the central banker, the smaller the reaction to an adverse real shock. It is important to note that this is only a partial equilibrium analysis. Since indexation is endogenous, an increase in CBI leads to an adjustment in the level of aggregate indexation. This comparative statics result will also hold in the more general case presented below.

\footnotetext{
${ }^{11}$ There exists another equilibrium with $b>1$ which is not considered because these types of wage contracts are not common. This equilibrium would yield $d>0$.
} 


\section{Individual Union Optimization}

Union $i$ minimizes the following expression with respect to $w_{i}^{0}$ and $b_{i}$ :

$$
E\left[l_{i}-l_{i}^{*}\right]^{2}=E\left[-\frac{1}{1-a_{1}}\left(w_{i}^{0}+b_{i}(d \theta+v)-\left(p^{e}+d \theta+v\right)-\theta_{i}-\ln a_{1}\right)-l_{i}^{*}\right]^{2}
$$

taking aggregate indexation (b) as given. Individual unions use (13) and (14) when optimizing, but they do not consider the effect of their choice on aggregate indexation. Thus, we assume:

$$
\frac{\partial b}{\partial b_{i}}=0
$$

Since aggregate indexation is not directly chosen, unions do not act like Stackelberg leaders. In particular, they do not consider what effect their choice will have on the central bank's stabilization parameter described in (14). ${ }^{12}$ This presents the possibility that there is an externality when unions do not coordinate. ${ }^{13}$

Union $i$ 's maximization with respect to the base nominal wage yields:

$$
w_{i}^{0}=p^{e}+\ln a_{1}-\left(1-a_{1}\right) l_{i}^{*}
$$

Thus, Union $i$ 's objective function can be rewritten as:

$$
E\left[\left(1-b_{i}\right)(d \theta+v)+\theta_{i}\right]^{2}
$$

The idiosyncratic component of the country-specific real shock and the nominal shock are assumed to be uncorrelated with the aggregate real shock:

$$
E\left[v \theta_{i}\right]=E[v \theta]=0 \text { and } E\left[\theta \theta_{i}\right]=\alpha_{i} \sigma_{\theta}^{2}
$$

The loss function in (18) can now be written without the expectations operator:

\footnotetext{
${ }^{12}$ In other words, $\partial d / \partial b_{i}=0$.

${ }^{13} \mathrm{An}$ analysis of this externality would require relaxing the assumption in (16). Ball (1988) and Waller and VanHoose (1992) study whether decentralized wage bargaining leads to a socially inefficient level of wage indexation. This question is not analyzed in this paper.
} 


$$
d^{2}\left(1-b_{i}\right)^{2} \sigma_{\theta}^{2}+\sigma_{\theta_{i}}^{2}+2 \alpha_{i} d\left(1-b_{i}\right) \sigma_{\theta}^{2}+\left(1-b_{i}\right)^{2} \sigma_{v}^{2}
$$

The first two terms of (20) are positive and represent the loss associated with a real shock. The third term is negative and shows how the magnitude of $|d|$ contributes to the stabilization effort. Finally, the fourth term is positive and represents the loss created by the nominal shock. In (20) we see the problem faced by Trade Union $i$ : an increase in $b_{i}$ lowers the cost of the nominal shock (fourth term) but also increases the cost of a real shock by reducing the countercyclical effect of the third term. Differentiating with respect to $b_{i}$ and defining the ratio of the shock variances to be $\sigma^{2} \equiv \frac{\sigma_{v}^{2}}{\sigma_{\theta}^{2}}$, we compute the optimal level of indexation for Union $i$ :

$$
b_{i}(d)=1+\frac{\alpha_{i} d}{d^{2}+\sigma^{2}} \text { or } 1-b_{i}(d)=\frac{\alpha_{i} d}{d^{2}+\sigma^{2}}
$$

Unions consider the aggregate level of indexation, the ratio of the shock variances and the level of CBI when computing the optimal level of indexation. ${ }^{14}$ Before discussing the properties of the individual trade union equilibrium indexation, it is necessary to compute the aggregate level of indexation.

\section{Aggregate Equilibrium}

The method used to compute the aggregate equilibrium is similar to Ball (1988) and Waller and VanHoose (1992). The goal is to find country-specific choices that are consistent with the aggregate level of indexation. Integrating both sides of (21) with respect to $i$ we get:

$$
1-b=-\frac{d}{d^{2}+\sigma^{2}}
$$

This results in a fifth degree polynomial in $(1-b)^{15}$. Analysis of this equilibrium is facilitated by using graphical methods ${ }^{16}$. To find aggregate indexation, consider the intersection of the $45^{\circ}$ degree line in $(1-b)$ and $f(1-b)$, where $f$ is given by:

\footnotetext{
${ }^{14}$ Although aggregate indexation and CBI do not explicitly appear in (14), $d$ is a function of $b$ and $c$.

${ }^{15}$ Note that $d$ is a function of $1-b$.

${ }^{16}$ The method is outlined in Eijffinger, Hoeberichts and Schaling (1995).
} 


$$
f(1-b)=\frac{-d}{d^{2}+\sigma^{2}}
$$

Comparative statics can be performed by shifting $f$. An increase (decrease) in the relative importance of nominal (real) shocks unambiguously shifts $f$ down (up) and results in higher (lower) indexation. ${ }^{17}$ This is a classic result from the optimal wage indexation literature (see Gray 1976). The result is intuitive since high indexation is thought to partially insulate the union from nominal shocks.

What is the impact of allowing country-specific shocks in a decentralized setting versus having all unions experience the same real shock? At the aggregate level nothing changes. The difference is that when all unions are assumed to experience a common shock, they choose the same level of indexation. When unions experience country-specific shocks, their indexation demands depend on the degree of correlation between the country-specific and aggregate shock. Indexation in Country $i$ is a linear and decreasing function of $\alpha_{i}$. This can be seen by rewriting equation (21) and recalling that $d<0$ :

$$
b_{i}\left(\alpha_{i}\right)=1+\left(\frac{d}{d^{2}+\sigma^{2}}\right) \alpha_{i}
$$

The less correlated a country's shock is with the aggregate, the higher its indexation demands. ${ }^{18}$

There are two ways of interpreting this result. The first relies on equation (20). When shocks were common, the optimal level of indexation was derived by considering the loss due to nominal and real shocks and equating the marginal cost and marginal benefit of indexation. In comparing a Union $i$ with positive (but less than perfect) correlation with aggregate shocks $\left(0<\alpha_{i}<1\right)$ to a union whose shocks are perfectly correlated with aggregate shocks $\left(\alpha_{i}=1\right)$, one can see that the marginal cost of higher indexation is lower (protection against real shocks, the third term) for Union $i$, while the marginal benefit of higher indexation is the same for both unions (protection against nominal shocks, the fourth term). This results

\footnotetext{
${ }^{17}$ Treating $1-b$ as the independent variable.

${ }^{18}$ Since $\alpha_{i}$ is not restricted in this paper, $b_{i}$ could be negative or greater than 1 . For countries joining a monetary union, it is reasonable to assume that $\hat{a}_{i}$ is positive and not too distant from 1 . In this case, the level of indexation for an individual country will satisfy $0 \leq b_{i} \leq 1$.
} 
in higher indexation for Union $i$. The second interpretation is more intuitive. Countries which are outliers use indexation to protect themselves against undesired MUCB interventions. Before MU, movements in the price level of their countries were either caused by nominal shocks (destabilizing) or were induced by their central bank reacting to an adverse country-specific real shock (stabilizing). After MU, additional destabilizing price level movements come from the MUCB's reaction to an aggregate shock that is not necessarily felt in the local economy. Higher indexation provides protection against this type of movements in the price level.

\section{Implications for Structural Convergence}

The effect of the creation of a MU on the economic structure of member countries is an important issue for policy makers in a single currency Europe. If economic structures converge, a common monetary policy will have similar real effects in member countries. If, on the other hand, economic structures remain different, or even diverge, the concept of an optimal common monetary policy will become more complicated. ${ }^{19}$

The issue of whether a MU promotes structural convergence remains an open question. In the realm of labor markets, Calmfors (2001) asks whether a MU increases incentives for national labor market reform; he identifies two opposite effects. On the one hand, the loss of autonomous monetary policy requires labor markets to be flexible when faced with idiosyncratic shocks, thus providing an incentive to undertake labor market reforms. On the other hand, pre-MU reforms have a direct impact on the incentives for the central bank to create surprise inflation, helping to reduce trend inflation. Post-MU, each national labor market is a small part of a larger "MU labor market," so the incentives to undertake labor market reform are reduced. The general conclusion is that "if the inflationary bias can be eliminated through the choice of appropriate monetary institutions," the first effect will dominate and MU will increase incentives for labor market reform. Sibert (1999) finds that when pre-MU national monetary policy has negative spillovers and labor market distortions tempt national governments to inflate, the creation of a MU can provide increased incentives for national governments to undertake structural reform. Beetsma and Jensen (1998) argue that although the

\footnotetext{
${ }^{19}$ The concept of optimal ECB policy is discussed in Benigno (2001).
} 
requirements for joining a $\mathrm{MU}$ force countries to undertake similar reforms, there is incentive to undo those reforms after being accepted to join the single currency. These models treat structural reform as a government choice variable.

The model presented in this paper differs from the previous literature on structural convergence in a MU by focusing on how agents within the labor market will endogenously adjust to the new monetary regime. The particular aspect of the labor market considered is nominal wage flexibility. The model shows that the key determinants of wage flexibility are the level of CBI and the nature of the stochastic shocks. If pre-MU levels of CBI vary across national central banks then the delegation of monetary policy to the MUCB causes all trade unions to face the same $\mathrm{CBI}$ and induces convergence in wage flexibility across member countries. Italy provides a striking example. Barrell (1990) discusses how the perceived commitment to the ERM and lower inflation expectations helped Italy to dismantle its national indexation system called scala mobile. The perception that Italy's monetary policy would be essentially set by the more conservative Bundesbank helped to convince labor market participants that there was less need to protect themselves against a loose monetary policy.

The second determinant of wage flexibility is the stochastic nature of the economy. The classic Gray (1976) result states that the level of indexation within a country will be a function of the relative shock variances. Consider the case in which pre-MU real and nominal shock variances are the same across countries. All else equal, this implies that each country has the same level of indexation before joining the MU. If real shocks are not perfectly correlated across countries the model predicts that, with the creation of a MU, nominal wage flexibility would increase in outlier countries as unions choose higher indexation. ${ }^{20}$ This would create divergence between a core country's and an outlier country's nominal wage flexibility.

The ultimate impact of a MU on business cycle correlation across member countries remains a controversial topic. Frankel and Rose (1998) and Rose (2000) present evidence that a MU increases trade and that increased trade leads to increased synchronization of business cycles. The model presented above would then predict that the combination of a single CBI for all member countries and homogeneous shocks should elicit a similar endogenous adjustment on the part of

\footnotetext{
${ }^{20}$ Alessina and Grilli (1992) identify Ireland, Greece and Portugal as these types of countries. Since the output series are partially determined by national monetary policies, the authors note that the creation of the ECB might affect their "outlier" status.
} 
each country's labor market, implying that the creation of a single currency should promote structural convergence between member countries. Kaleml-Ozcan, Sorensen and Yosha $(1999,2001)$ present evidence that increased capital market integration promotes increased risk sharing and this, in turn, leads to more regional specialization. This regional specialization tends to make business cycles less correlated across countries. Under this scenario, the model would likely predict a different cross-country labor market adjustment to MU, and thus some degree of structural divergence.

\section{Conclusion}

The literature on the European single currency has documented existing differences in national monetary transmission mechanisms, but has not addressed the impact of the creation of the single currency on the degree of nominal wage flexibility in member countries. The model presented above studies how the creation of a MU affects incentives trade unions face when bargaining wage contracts. The endogenous reaction of the labor market to the new monetary regime results in trade unions in outlier countries choosing a more flexible nominal wage. Intuitively, the optimal wage contract in outlier countries is structured to reduce the impact of undesired monetary interventions on employment and real wages. This is achieved by creating a more flexible nominal wage, implying that the common monetary policy would have a larger real effect on core countries and induce flatter output response in outlier countries. Benigno (2001) shows that this type of heterogeneity across countries has important implications for the design of the optimal common monetary policy.

The literature on structural convergence in a MU has focused on structural change as a government choice variable. In the model presented above, nominal wage flexibility is determined by labor market participants. The paper identifies two possible effects on structural convergence. First, if the pre-MU degree of central bank conservativeness differed across member countries, then the new strategic interaction between trade unions and the new common central bank causes the degree of nominal wage flexibility to converge across countries. The second effect is less clear. If one believes that a common currency promotes business cycle correlation, then indexation demands should converge across countries. But if a MU increases specialization and results in more pronounced cross-country business cycle asynchronization, the creation of the single currency 
should induce a different reaction on the part of national labor markets and may result in structural divergence.

\section{Appendix}

\section{A. Real Wage Target}

In Bar-Ilan and Zanello (1996), the trade union's objective function includes both an employment target and a real wage target. This section assumes that the objective function for the union is given by:

$$
E\left\lfloor\left(l_{i}-l_{i}^{*}\right)^{2}+s\left(w-p-\left(w_{i}-p\right)^{*}\right)^{2}\right\rfloor
$$

where $s$ is the weight placed on the real wage objective $\left(w_{i}-p\right)^{*}$ is the union's real wage target. Equation (21) becomes:

$$
b_{i}(d)=1+\frac{\alpha_{i} d}{\left(s\left(1-a_{1}\right)^{2}+1\right)\left(d^{2}+\sigma^{2}\right)}
$$

The fixed point of this equation is the aggregate level of indexation. As one would expect, aggregate indexation is an increasing function of the weight $s$. Even though this alteration changes the level of indexation chosen by the union, the properties of the equilibrium discussed above still hold.

\section{B. Money Supply as the Choice Variable}

Following Waller and VanHoose (1992), an aggregate demand equation is added:

$$
y=m+v-p
$$

where $m$ is the money supply and $v$ is an iid nominal shock variable.

The equilibrium price level can be solved for as a function of the central bank choice variable $(m)$ :

$$
p=\frac{1}{1+a(1-b)}\left(m+v-a b p^{e}+a w^{0}-a \ln \left(a_{1}\right)-(1+a) \theta\right)
$$


The central bank chooses the money supply after the realization of the real shock and before the realization of the nominal shock. Once again, the previous results do not change qualitatively. There is still a partial indexation equilibrium which is sensitive to the combination of stochastic variances and central bank independence. Thus, the fundamental results of the paper are not sensitive to the two alterations presented above.

\section{Acknowledgement}

I would like to thank Carl Walsh, Michael Hutchison, Michael Dooley, Alex Cukierman, Antonio Garcia, Jerry McIntyre, and seminar participants at the University of California, Santa Cruz, the Spring Meeting of Young Economists, Berlin, and the Tel Aviv University Macroeconomics Workshop. All remaining errors are mine. The views expressed in this paper are solely those of the author and do not represent the policy of the U.S. Department of the Treasury.

Received 18 February 2002, Accepted 17 September 2002

\section{References}

Ahmed, Shaghil (1987), "Wage Stickiness and the Non-Neutrality of Money: A Cross Industry Analysis," Journal of Monetary Economics, 20, 25-50.

Alessina, Alberto and Vittorio Grilli (1992), “The European Central Bank: Reshaping Monetary Politics in Europe," in Canzoneri, M., Grilli, V., Masson, P. (eds), Establishing a Central Bank: Issues in Europe and Lessons from the U.S., Cambridge University Press, 1992, 49-77.

Ball, Laurence (1988), "Is Equilibrium Indexation Efficient?," Quarterly Journal of Economics, 413, 299-312.

Bar-Ilan, Avner and Alessandro Zanello (1996), "On the Absence of Positive Wage Indexation," Economica, 63, 687-699.

Barrell, R. (1990), "Has the EMS Changed Wage and Price Behavior in Europe?," National Institute Economic Review, November 1990, 64-72.

Barro, Robert and David Gordon (1983), "Rules, Discretion and Reputation in a Model of Monetary Policy," Journal of Monetary Economics, 22, 101-121.

Beetsma, Roel and Henrik Jensen (1998), "Structural Convergence Under Reversible and Irreversible Monetary Unification," Economic Policy Research Unit, Copenhagen Business School, mimeo.

Benigno, Pierpaolo (2001), “Optimal Monetary Policy in a Currency Area," CEPR No. 2755. 
Bils, Mark (1991), "Indexation and Contract Length in Unionized U.S. Manufacturing," in Randall Eberts and Erica Grosham (eds.), Structural Changes in U.S. Labor Markets: Causes and Consequences, London, England, 145-171.

Calmfors, Lars (2001), "Unemployment, Labour-Market Reform and Monetary Union," Journal of Labor Economics, 19 (2), 265-289.

Calmfors, Lars and Asa Johansson (2002), "Nominal Wage Flexibility, Wage Indexation and Monetary Union," Seminar Paper No. 716, IIES, Stockholm University.

Christofides, L. and A. Stark (1996) “The Incidence and Intensity of Wage Indexation: An Empirical Analysis," Applied Economics, 28, 233-240.

Cukierman, Alex and Francesco Lippi (1999), "Central Bank Independence, Centralization of Wage Bargaining, Inflation and Unemployment: Theory and Evidence," European Economic Review, 43 (7), 1395-1434.

Danziger, Leif (1988), "Real Shocks, Efficient Risk Sharing, and the Duration of Labor Contracts," Quarterly Journal of Economics, 103 (2), 435-440.

Devereaux, Michael (1987), "The Effect of Monetary Variability on Welfare in a Simple Macroeconomic Model," Journal of Monetary Economics, 19, 427-435.

Dornbusch, Rudiger, Carlo A. Favero, and Francesco Giavazzi (1998), "The Immediate Challenges for the European Central Bank," NBER Working Paper No. 6369, January 1998.

Duca, John and David VanHoose (1991), "Optimal Wage Indexation in a Multisector Economy," International Economic Review, 32 (4), 859-867.

Eichengreen, Barry (1993), "Epilogue: Three Perspectives on the Bretton Woods System," in M. Bordo and B. Eichengreen (eds.), A Retrospective on the Bretton Woods System, The University of Chicago Press, 621-658.

Eijffinger, S., Hoeberichts, H. and E. Schaling (1995), "Optimal Conservativeness in the Rogoff (1985) Model: A Graphical Closed Form Solution," Center for Economic Research, Tilburg University, Working Paper No. 95121.

Emerson, M., Gros, D., Italianer, A., Pisani-Ferry, J., Reichenbach, H. (eds.) (1990), One Market, One Money, Oxford University Press.

Fethke, Gary (1985), "The Conformity of Wage-Indexation Models with Stylized Facts," American Economic Review, 75 (4), 856-861.

Fischer, Stanley (1977), "Long-Term Contracts, Rational Expectations, and the Optimal Money Supply Rule,” Journal of Political Economy, 85 (1), 163-90.

Frankel, Jeffrey and Andrew Rose (1998), "The Endogeneity of the Optimum Currency Area Criteria," Economic Journal, 108 (449), 1009-1025.

Gerlach, S. and F. Smets (1995), "The Monetary Transmission Mechanism: Evidence from the G-7 Countries," BIS Discussion Paper, March 1995, No. 26.

Gray, Jo Anna (1976), "Wage Indexation: A Macroeconomic Approach," Journal of Monetary Economics, 2, 221-235.

Gray, Jo Anna (1978), “On Indexation and Contract Length,” Journal of Political Economy, 86 (1), 1-18.

Holland, A. Steven (1995), "Inflation and Wage Indexation in the Postwar United States," 
The Review of Economics and Statistics, 77 (1), 172-176.

Hutchison, Michael M. and Carl E. Walsh (1998), "The Output Inflation Tradeoff and Central Bank Reform: Evidence from New Zealand,” Economic Journal, 108 (448), 703-725.

Kalemli-Ozcan, Sebnem, Bent Sorensen and Oved Yosha (1999), "Risk Sharing and Industrial Specialization: Regional and International Evidence," mimeo.

Kalemli-Ozcan, Sebnem, Bent Sorensen and Oved Yosha (2001), "Economic Inegration, Industrial Specialization and the Asymmetry of Macroeconomic Fluctuations," Journal of International Economics, 55, 107-137.

Leichter, Jules and Carl E. Walsh (2000), "Different Economies, Common Policy: Policy Trade-offs under the ECB," mimeo.

Murphy, Kevin (2000), "What Effect Does Uncertainty Have on the Length of a Labor Contract," Labour Economics, 7, 181-201.

Ramaswamy, Ramana and Torsten Slok (1998), "The Real Effects of Monetary Policy in the European Union: What are the Differences?," IMF Staff Papers, 45 (2), 374-399. Sala, Luca (2000), "Monetary Transmission Mechanism in the Euro Area: A Factor Model Approach," ULB-ECARES, mimeo.

Sibert, Anne (1999), "Monetary Integration and Economic Reform," Economic Journal, 109 (452), 78-92.

VanHoose, David and Christopher Waller (1991), "Discretion, Wage Indexation, and Inflation,” Southern Economic Journal, 58 (2), 356-367.

Waller, Christopher and David VanHoose (1992), "Discretionary Monetary Policy and Efficient Wage Indexation,” Quarterly Journal of Economics, 431, 1451-1460.

Walsh, Carl E. (1995), "Central Bank Independence and the Short-Run Output-Inflation Trade-off in the European Community," in Eichengreen, B., J. Frieden and J. von Hagen (eds.), Monetary and Fiscal Policy in an Integrated Europe, Springer, 12-37. 